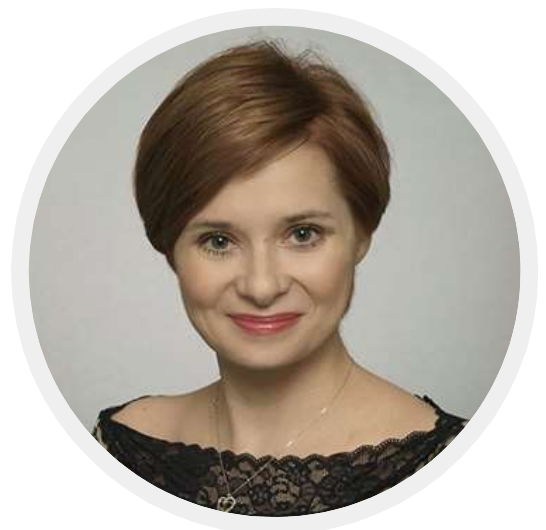

\title{
Катажина Вітковська-Хжчонович
}

Доктор габілітований, професор

Кафедра Міжнародного та Європейського Права

Факультет права та адміністрації

Університет Миколая Коперника у Торуні, Польща

kwch@umk.pl

\section{РУЙНАЦІЯ ПОЛЬСЬКОГО СУДОЧИНСТВА В 2015-2019 РОКАХ - OKРЕМІ ПИТАННЯ}

\section{DESTRUCTION OF THE POLISH JURISDICTION IN 2015-2019 - SELECTED QUESTIONS}

\author{
Katarzyna Witkowska-Chrzczonowicz \\ Doctor of Habilitation, Professor, Department of International and European Law, Faculty of Law and Admin- \\ istration, Nicholas Copernicus University in Torun, Poland \\ kwch@umk.pl
}

Abstract $\mid \begin{aligned} & \text { The destruction of the judiciary in Poland began in } 2015 \text { and affected not only the general courts } \\ & \text { but also the Constitutional Court, the Supreme Court and the National Judicial Council. This pro- }\end{aligned}$ cess is related to the degradation of state institutions, violation of the Constitution by the state bodies which are obliged to adhere to its rules as well as by the state policy which often contravenes the law.

The failure of the Constitution to comply with state bodies, who are obliged by its rules, as well as by public policy, which is often contrary to law.

Such actions have caused a considerable weakening of Poland's position in the international arena, particularly in the European Union. The current institutional crisis in Poland began in 2015, when the political party « Law and Justice» won the parliamentary elections in Poland. From that time the large-scale activities started, aimed at subordinating the political goals of the ruling majority to the judicial system in Poland.

The events under investigation are reflected in Poland's position in the European Union, the institutions of which commenced the proceedings against Poland for the protection of the rule of law in accordance with art. 7 of the Treaty on European Union. In addition, the EU Court has repeatedly responded to the aforementioned processes in Poland, effectively defending the Polish Constitution, in situations when national authorities called upon to perform this function cannot or are not willing to perform it properly. The actions of the Polish authorities after 2015 are estimated in the European Union as a manifestation of authoritarian tendencies and are considered to be a lot more of a threat to the idea of the European Union and its stability than Brexit.

The research touches upon the political changes that have affected the Polish justice system and other institutions since 2015. The abovementioned crisis concerns, in particular, the Constitutional Court, the 
Supreme Court, the National Council for the Judiciary and the general courts. Special attention is devoted to the problems of influencing the constitutional judiciary, the politicization of the National Judicial Council, and the general institutional crisis in Poland.

Keywords: judiciary, political influence on the judiciary, independence of the court.

\section{Анотація Руйнування судочинства у Польщі розпочалось у 2015 році і торкнулося не лише} загальних судів, але і Конституційного Суду, Верховного Суду та Національної Ради Судочинства. Цей процес пов'язаний з деградацією державних інститутів, порушенням Конституції державними органами, які зобов'язані дотримуватися її норм, а також з державною політикою, яка часто суперечить праву. Наслідком таких дій є стрімке послаблення позиції Польщі на міжнародній арені, зокрема в Європейському Союзі. Сучасна інституційна криза у країні розпочалась у 2015 р., коли в Польщі на парламентських виборах перемогла партія «Право і Справедливість». Відтоді розпочато масштабну діяльність, спрямовану на підпорядкування політичним цілям правлячої більшості системи судочинства у Польщі.

Описані події відображаються на позиції Польщі в Європейському Союзі, інститути якого розпочали проти Польщі процедуру захисту верховенства права відповідно до ст. 7 Договору про Європейський Союз. Крім того, Суд ЄС вже декілька разів реагував на згадувані процеси у Польщі, стаючи фактичним захисником польської Конституції у ситуації, коли національні органи, покликані виконувати цю функцію, не можуть або не хочуть її виконувати в належний спосіб. Дії польської влади після 2015 р. оцінюються в Європейському Союзі як прояв авторитарних тенденцій і вважається, що для цілісності Європейського Союзу та його стабільності вони $є$ набагато більшою загрозою, ніж Brexit.

Дослідження стосується політичних змін, які торкнулися польської системи правосуддя та інших інституцій від 2015 року. Вищезгадана криза стосується, зокрема, Конституційного Суду, Верховного Суду, Національної Ради Судочинства та загальних судів. Окрему увагу присвячено проблемам впливу на конституційне судочинство, політизації Національної ради судочинства, а також загальній інституційній кризі в Польщі.

Ключові слова: судова влада, політичний вплив на судову владу, незалежність суду.

\section{Вступ}

Руйнування судочинства у Польщі розпочалось у 2015 році і зачепило не лише загальні суди, але і Конституційний Суд, Верховний Суд та Національну Раду Судочинства. Цей процес пов'язаний з деградацією державних інститутів, недотриманням Конституції державними органами, які зобов'язані дотримуватися ії норм, а також з державною політикою, яка часто суперечить праву. Наслідком таких дій є яскраве послаблення позиції Польщі на міжнародній арені, зокрема в Європейському Союзі. Сучасна інституційна криза у Польщі розпочалась у 2015 р., коли в Польщі на парламентських виборах перемогла партія «Право і Справедливість». Відтоді розпочато масштабну діяльність, спрямовану на підпорядкування політичним цілям правлячої більшості, системи судочинства у Польщі.

\section{I. Деструкція польського Конституційного Суду}

Польський Конституційний Суд став першою інституцією здійсненого «ворожого поглинання». Найважливіші зміни щодо нього були запроваджені у 2015-2016 роках, передусім шляхом внесення змін у закон про Конституційний Суд у 2015 р. ${ }^{1}$, а згодом через новий закон про Конституційний Суд від 22 липня 2016 року². Варто представити найважливіші проблеми, пов'язані з функціонування КС. Проблеми стосуються, зокрема, допущення до розгляду справ так званих суддівдублерів, обраних всупереч нормам Конституції Сеймом VIII каденції та прийняття їхньої присяги

\footnotetext{
1 Dz. U. z 20 grudnia 2015 p., poz.1928. URL: http://prawo.sejm.gov.pl/isap.nsf/download.xsp/WDU20150001928/T/ D20151928L.pdf

2 Dz. U. z 1 sierpnia 2016 p., poz. 1157. URL: http://prawo.sejm.gov.pl/isap.nsf/download.xsp/WDU20160001157/T/ D20161157L.pdf
} 
Президентом Польщі, відсутності опублікування або опублікування зі значним запізненням рішень КС, «невизнання» деяких рішень КС урядом, призначення на вільні місця у Суді суддів, оминаючи водночас суддів, обраних ще Сеймом VII каденції, призначення на ці ж місця осіб надзвичайно суперечливих, аполітичність яких породжує сумніви та застереження, зокрема таких як Кристина Павлович чи прокурор часів ПРЛ і колишній депутат «Права і Справедливості» Станіслав Пьотрович. Врешті варто наголосити на призначенні теперішньої Голови КС Президентом Польщі з порушенням норм права.

Про зміни в Конституційному Суді висловилася в двох висновках Венеційська Комісія, що $\epsilon$ дорадчим органом Ради Європи, яка представила в них надзвичайно критичні зауваження, основні

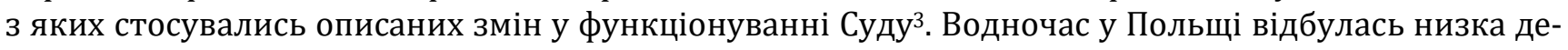
монстрацій як прихильників змін в КС, так і противників. Ця криза поглиблюється і породжує сумніви щодо справедливості рішень, винесених суддями КС, обраними у спосіб, що суперечить Конституції, водночас послаблюючи позиції Польщі на міжнародній арені. Через відсутність поваги до висновків Венеційської Комісії, критики опозиції, інституцій ЄС, Ради Європи, Уповноваженого 3 прав людини, значної частини польської академічної та правничої спільноти, неготовності вирішити суперечку правлячою партією, Європейська Комісія звернулась до Ради ЄС про відкриття проти Польщі процедури щодо захисту верховенства права на підставі ст. 7 Договору про ЄC, а в березні 2018 р. Європарламент прийняв резолюцію щодо ситуації в Польщі, в якій підтримав Комісію в цьому питанні.

Як поправки до закону 2015 р., так і новий закон про Конституційний Суд не мають - як хотіли б показати суспільству їхні автори - «відновлювального» характеру, а радше дані зміни ведуть до деградації та паралізують Конституційний Суд як орган, покликаний здійснювати фактичний контроль за відповідністю дій парламенту Конституції. Джерелом цих змін є політичні амбіції, аби з порушення конституційного принципу поділу влади отримати неконтрольований ніким або контрольований de facto фасадний орган ${ }^{4}$. Сучасний стан дискусій навколо Конституційного Суду призвів до значного зниження довіри до цього органу, йдеться і про довіру інституційну, i довіру громадян. Як слушно і сумно водночас зазначається в літературі, «Польща є першою державою-членом $Є С$, проти якої процедура захисту верховенства права відповідно до ст. 7 Договору про ЄC не лише зайшла так далеко, але взагалі була застосована вперше"5.

\section{II. Проблема політизації Національної Ради Судочинства}

У випадку Національної Ради Судочинства (КРС), яка є конституційним органом Польщі, що покликаний забезпечувати безсторонність суддів та незалежність судів - головна проблема полягає в тому, що при призначенні на посади в КРС ключову роль відіграє політичний чинник, а вплив суддівського чинника, який має бути найбільш видимим, практично маргіналізований. Це особливо помітно у контексті нових норм закону, що регулює склад і статус КРС 6 , Венеційська комісія видала висновок ${ }^{7}$ про суперечливість змін у нормах, що регулюють статус КРС, який парламентська більшість в Польщі особливо не брала до уваги. На думку Венеційської Комісії, у державі

\footnotetext{
3 Opinia Komisji Weneckiej z dnia 11 marca 2016 r. W sprawie zmiany ustawy o Trybunale Konstytucyjnym z dnia 22 grudnia 2015 r., Opinion on amendments to the Act of 25 June 2015 on the Constiututional Tribunal of Poland, adopted by the Venice Commission at its 106th Plenary Session (venice,11-12 March 2016), CDL-Ad (2016) 001-e. oraz Opinia Komisji Weneckiej z dnia 14 października 2016 r. - Opinion on the Act on the Constitutional Tribunal, adopted by the Venice Commission at its 108 th Plenary Session (Venice ,14-15 October) , CDL-AD (2016)026-e. Por. Szmyt A. Destrukcja Trybunału Konstytucyjnego w Polsce w świetle opinii Komisji Weneckiej, „Gdańskie Studia Prawnicze”. Tom XL. 2018. s. 649 i n.

4 Szmyt A. Destrukcja Trybunału Konstytucyjnego w Polsce w świetle opinii Komisji Weneckiej.Gdańskie Studia Prawnicze". Tom XL. 2018. s. 660.

5 Majkowska-Szulc S. Konsekwencje naruszenia wartości Unii Europejskiej na przykładzie unicestwienia polskiego Trybunału Konstytucyjnego w 20 lat po uchwaleniu Konstytucji RP.Gdańskie Studia Prawnicze”. Tom XL. 2018. s. 713.

6 Dz.U. z 2018 r. poz. 3, Dz.U. z 2019 r. poz. 84 tekst jednolity.

7 Opinion on the Draft Act amending the Act on the National Council of the Judiciary; on the Draft Act amending the Act on the Supreme Court, proposed by the President of Poland, and on the Act on the Organisation of Ordinary Courts, adopted by the Commission at its 113th Plenary Session (Venice, 8-9 December 2017), CDL-AD(2017)031-ePoland.
} 
верховенства права значна частина членів суддівських рад повинна обиратися суддями, а відповідно до закону Сейм може обирати кандидатів, які мають мінімальну підтримку серед суддів. Проблему поглиблює додатково факт спільної для всіх членів каденції, в той час, коли в Європі поширені несинхронізовані каденції, коли разом працюють члени, обрані парламентами різних скликань. Це підвищує ймовірність, що члени будуть представниками різних політичних поглядів, що своєю чергою підвищує незалежність органу. Натомість спільний вибір всіх членів може призвести до політично одноманітної КРС. На думку Венеційської Комісії (що є слушним), такі норми послаблюють незалежність судової влади. Відповідно до нових положень обрано членів нової КРС, а в розрахунку на 10 тис. польських суддів представлено лише 18 (!) кандидатур до цього органу - головним чином осіб, які тісно співпрацюють з міністром юстиції Збіґнєвом Зьобро або які завдячують йому своїм кар'єрним зростанням. Листи підтримки до КРС зберігаються в таємниці та не розголошуються донині. Звернімо увагу, що 28 червня 2019 р. Вищий Адміністративний Суд зобов'язав опублікувати лист до КРС ${ }^{8}$, аргументуючи, що інформація, яка міститься в додатках і включає списки суддів, які підтримують кандидатури членів до КРС, є публічною інформацією і підлягає оприлюдненню, але це рішення до сьогодні не виконане, що в демократичній державі $\epsilon$ неприпустимим. 3 огляду на активну участь Національної Ради Судочинства у процесі висунення суддів Верховного Суду, справи Ради перейшли у наступну стадію кризи навколо Верховного Суду, яка триває у Польщі від 2017 р. На жаль, доводиться констатувати, що у вересні 2018 року Європейська Мережа Рад Судочинства зупинила членство КРС з огляду на «недотримання умов незалежності від виконавчої влади»9.

\section{III. Верховний Суд і проблема інституційної кризи у Польщі}

2017-2019 роки принесли багато несприятливих змін у Верховному Суді (BC) (разом з новим законом про ВС від 2017,10 ухваленим після численних протестів проти первинного проєкту, вето Президента, а потім скерування тим ж Президентом такого ж неконституційного проєкту закону про ВС для роботи над ним в парламенті). Найсуперечливіші зміни щодо Верховного Суду 3 точки зору поваги до принципів верховенства права - це примусове та неконституційне відправлення у відставку суддів ВC (зокрема і I Голови ВC), які досягли 65-річного віку, створення Дисциплінарної Палати Верховного Суду, яка de facto не є судом, а також проблема неправомірного призначення нових суддів ВС в ситуації, коли у процедурі бере участь нова КРС, створена з порушенням норм Конституції, окрім того існує проблема проваджень відкритих Дисциплінарною Палатою ВС проти суддів, які активно критикують чи ставлять під сумнів напрямок змін польського права у сфері правосуддя.

\section{IV. Так званий «закон намордника» (репресивний) як інструмент тиску на польських суддів}

Одним з елементів тиску політиків на польських суддів є ухвалений 20.12.2019 р. Сеймом так званий «закон намордника» (репресивний)11. Проєкт закону подала вночі з 12 на 13 грудня 2019 р. група депутатів «Права і Справедливості». Після оприлюднення проєкту відбулись численні демонстрації в усій Польщі проти положень зазначеного закону.

Закон прийнятий у Сеймі, незважаючи на лист віце-президента Європейської Комісії Віри Журової, адресований Президенту Польщі, Спікеру Сейму і Сенату та Прем'єр-міністру у справі проєкту закону, який «викликає занепокоєння Європейської Комісії». В листі вона закликала польську владу проконсультуватися з Венеційською Комісією Ради Європи і призупинити процес

\footnotetext{
8 Wyrok NSA z 28 czerwca 2019 r., sygn., akt. I OSK, 4282/18. URL: http://n-22-3.dcs.redcdn.pl/file/o2/tvn/webcontent/m/p1/f/5bce843dd76db8c939d5323dd3e54ec9/193978e1-5cd4-4cd9-8d01-ae5002551c87.pdf

9 Офіційний веб-сайт електронної газети «Rzeczpospolita». Розділ: Право. URL: https://www.rp.pl/Sedziowie-i-

sady/309179953-KRS-zawieszona-w-Europejskiej-Sieci-Rad-Sadownictwa.html

10 Ustawa z dnia 8 grudnia 2017 r. o Sądzie Najwyższym. Dz. U. z 2018 r. poz. 5. z późn. zm.

11 Ustawa o zmianie ustawy - Prawo o ustroju sądów powszechnych, ustawy o Sądzie Najwyższym oraz niektórych innych ustaw ,uchwalona na pos. nr 2 dnia 20-12-2019. URL: http://orka.sejm.gov.pl/opinie9.nsf/nazwa/69_u/\$file/69_u.pdf
} 
розгляду проєкту до часу проведення необхідних консультацій ${ }^{12}$. Закон було прийнято, незважаючи на застереження Уповноваженого з прав людини, який заявляв у Сеймі, що даний проєкт порушує Конституцію, принцип верховенства права, нівелює судові процедури, а його прийняття є дорогою до правового «polexitu»13. Аналогічно у 3МІ цей проєкт прокоментувала професор Ева Летовська, називаючи його «недемократично образливим» 14 .

Прийняті поправки, зокрема Закону про судоустрій і Закону про Верховний Суд, а також про адміністративні та військові суди, і прокуратуру, запроваджують дисциплінарну відповідальність суддів за дії або бездіяльність, які можуть перешкоджати функціонуванню судової влади, за дії, що ставлять під сумнів ефективність призначення судді, а також за «публічну діяльність, несумісну 3 принципами безсторонності суддів та незалежності судів». Крім того, найбільш суперечливими $\epsilon$ положення закону, що дисциплінарний уповноважений матиме право відкривати провадження у кожній справі, що стосується судді. Новий закон збільшує повноваження Палати Надзвичайного Контролю і Публічних Справ Верховного Суду про вирішення справ у випадку оскарження процесуального статусу судді або його повноважень здійснювати правосуддя. Вирішення цих справ належатиме виключно до Палати Надзвичайного Контролю. Дисциплінарна Палата Верховного Суду наділена компетенцією розглядати заяви про відхилення суддівського та прокурорського імунітету. Поправки також змінюють процедуру вибору I Голови Верховного Суду. Кандидата на цю посаду може висунути будь-який суддя цього Суду. Нові положення забороняють оскаржувати повноваження судів і трибуналів, конституційних органів держави до Верховного Суду. Забороняється також оцінювати законність призначення суддів на посаду і їх повноважень Верховним Судом чи іншим органом влади ${ }^{15}$. На момент написання цієї статті закон скерували до Сенату, в якому «Право і Справедливість» не має більшості після парламентських виборів, що відбулись восени 2019 року. Спікер Томаш Гродзкі оголосив про різносторонні консультації з юристами, експертами, він має намір відвідати віцепрезидента Європейської Комісії у Брюсселі, яка відповідає за питання верховенства права в ЄС, а також звернутися по допомогу до Венеційської Комісії. Вірогідним є сценарій, що Сенат відхилить законопроєкт повністю, а Сейм його ухвалить знову, а Президент підпише.

\section{V. Європейський Союз і Суд Європейського Союзу у процесі порушення принципів вер- ховенства права у Польщі}

Польща з «вершини демократичних змін» стала першою в історії Європейського Союзу державою, щодо якої розпочато процедуру захисту верховенства права, яка регулюється ст. 7 Договору про ЄС, про що з жалем констатуємо.

Натомість, в останній час так званих «реформ» польського судочинства, активним, дієвим та ефективним захисником польської Конституції став (як не парадоксально) Суд Європейського Союзу. Можна з полегшенням стверджувати, що, однак, п'ятнадцять років тому Польщі вдалося вступити в Європейський Союз і, як показує досвід, членство в цій організації є для Польщі своєрідним аварійним, зовнішнім «запобіжником», особливо в ситуації, коли хтось цілеспрямовано та систематично вимикає інші польські запобіжники в системі державних органів, «демонтуючи» по порядку: Конституційний Суд, Верховний Суд, Національну Раду Судочинства чи підриваючи в очах

\footnotetext{
12 Офіційний веб-сайт електронної газети «Newsweek Polska». Розділ: Політика.URL: https://www.newsweek.pl/polska/polityka/komisja-europejska-interweniuje-w-sprawie-sadow-chce-wstrzymania-prac-nad-ustawa/k9fek5g 13 Tezy wystąpienia Rzecznika Praw Obywatelskich z dnia 20.12.2019 r. w Sejmie. URL: https://www.rpo.gov.pl/pl/content/rpo-w-sejmie-ten-projekt-dewastuje-procedury-sadowe-i-grozi-polexitem 14 Офіційний веб-сайт електронної газети «ОКО.press». Доповідь Проф. Еви Летовської. URL: https://oko.press/prof-letowska-to-projekt-niekonstytucyjny-niedemokratycznie-obrazliwy-dokonuje-siepolexit/?utm_medium=Social\&utm_source=Facebook\&fbclid=IwAR3vHxWzgzvzMGh3P0VPZL2Vc8dh_DBVqy8oWhu_Y76Wqo W4HkJ4Z_bGcEI\#Echobox=1576196077

15 Офіційний веб-сайт електронної газети «Newsweek Polska». Розділ: Політика.

URL: https://www.newsweek.pl/polska/polityka/sejm-uchwalil-ustawe-kagancowa-pis-blyskawicznie-przepycha-noweprzepisy/x6qf32p
} 
громадян авторитет Уповноваженого з прав людини та польських суддів, загалом - систему правосуддя in genere.

Суд Європейського Союзу (Суд ЄС) підтвердив, що він відноситься до охоронців конституційних цінностей, «спільних» для держав-членів ЄС, видаючи низку рішень, які реально вплинули на відновлення стану відповідно до Конституції Польщі, або також дали зрозуміти (сподіваємось певною мірою) політичним представниками, які приймають рішення, що в Польщі неможливо проводити «кожну» реформу, яку вони захочуть провести, оскільки «є ще Суд у Люксембурзі». Невиконання договірних зобов'язань та рішень Суду є простим способом спершу до маргіналізації, а потім до виключення з Європейського Союзу. 3 огляду на статус так званої держави з низьким рівнем верховенства права, існує можливість виключення, хоча установчі документи ЄС expressis verbis цього не передбачають 16.

Протягом цих кількох років процесів, пов'язаних з підпорядкуванням польської судової влади виконавчій владі, Суд ЄС видав декілька цікавих рішень щодо ситуації в Польщі.

Варто згадати рішення віцепрезидента Суду ЄС від 19 жовтня 2018 р.17. Відповідно до цього рішення, Польща зобов'язана негайно призупинити застосування норм національного законодавства щодо зниження пенсійного віку та переходу у стан спочинку (відставку) суддів Верховного Суду. Слушною $є$ думка, що це рішення $є$ «далекосяжним» 18 і містить три рідко використовувані Судом ЄС механізми: застосування тимчасових заходів, використання підстави «терміновості» та вимога щомісячного контролю виконання зазначеного рішення Польщею. Врешті (після декількох безрезультатних дискусій у 3MI) прийнято, а потім 17 грудня 2018 р. Президент (даючи абсолютно непотрібні та несумісні зі статусом глави держави коментарі у ЗМI) ${ }^{19}$ підписав Закон про зміну закону про Верховний Суд²0, який повинен був задовільнити зміст вимог, які були в рішенні віцепрезидента Суду ЄС від 19 жовтня 2018 року.

Ще одним важливим рішення для оцінки інституційної кризи у Польщі $є$ рішення Суду ЄС від 19 листопада 2019 р.21, в якому - підсумовуючи - було визнано, що «Суд повинен перевірити незалежність нової Дисциплінарної Палати польського Верховного Суду з метою встановлення, чи цей орган може розглядати спори щодо переходу суддів Верховного Суду у стан спочинку, чи такі спори мають розглядатися іншим судом, який відповідає принципам незалежності». Суд вирішив, що неприпустимим $\epsilon$ те, що спори щодо застосування законодавства $€ С$ можуть належати до виключної компетенції суду (органу), який не вважається незалежним і безстороннім, а така ситуація виникає при об’єктивних обставинах, в яких був створений зазначений орган, а також спосіб призначення його членів «може спричинити обгрунтовані сумніви» щодо його незалежності від зовнішніх факторів, зокрема впливу законодавчої та виконавчої влади. Ці елементи «можуть (...) призвести до відсутності в цього органу ознак незалежності та безсторонності, що може підірвати

\footnotetext{
16 Barcz J. Podsumowanie i wnioski (w:) Barcz J., Zawidzka-Łojek A. (red.), Sądowe mechanizmy ochrony praworządności w Polsce w świetle najnowszego orzecznictwa Trybunału Sprawiedliwości UE. Warszawa 2018. s. 150.

17 Sprawa C-619/18R Komisja p. Polsce. ECLI:EU:C:2018:910, Tekst postanowienia dostępny jest na stronie. URL: https://curia.europa.eu/jcms/upload/docs/application/pdf/2018-10/cp180159pl.pdf (dostęp:30.12.2018).

18 Офіційний веб-сайт польського радіо RMF24. URL: https://www.google.pl/amp/s/www.rmf24.pl/newsamp-mamy-pelnatresc-postanowienia-tsue,nld,2646857

19 Офіційний сайт новин телебачення TVN24.PL. Доповідь Президента Польщі. URL: https://www.tvn24.pl/wiadomosci-zkraju,3/prezydent-o-sedziach-i-reformie-sadownictwa,896188.html

20 Ustawa z dnia 21 listopada 2018 r. o zmianie ustawy o Sądzie Najwyższym, Dz. U. z 2018 r., poz. 2507.

21 Wyrok TS z 19.11.2019 r. w składzie Wielkiej Izby w sprawach połączonych C-585/18, C-624/18iC-625/18A.K. / Krajowa Rada Sądownictwa oraz CPiDO / Sąd Najwyższy, W przedmiocie pytania pierwszego w sprawach C 624/18 iC625/18 W przedmiocie pytań w sprawie C 585/18 oraz pytań drugiego i trzeciego w sprawach C624/18 iC625/18, W przedmiocie dopuszczalności pytań drugiego i trzeciego w sprawach C 624/18 iC625/18W przedmiocie merytorycznego rozpoznania pytań drugiego i trzeciego w $\begin{array}{lllll}\text { sprawach } & \mathrm{C} & 624 / 18 \quad \text { iC625/18. } & \text { URL: }\end{array}$ content/m/p1/f/de03beffeed9da5f3639a621bcab5dd4/04584076-bc7e-4058-94fa-2eb6c31b3c70.pdf Por. także Trybunał Sprawiedliwości Unii Europejskiej KOMUNIKAT PRASOWY nr 145/19Luksemburg, 19 listopada 2019r. URL: http://n-516.dcs.redcdn.pl/file/o2/tvn/web-content/m/p1/f/de03beffeed9da5f3639a621bcab5dd4/ac2d25fd-a754-4f51-8399-

b606d3db5c32.pdf
} 
довіру, яку має викликати судова влада у демократичному суспільстві». Однак чи справді виникла така ситуація у випадку, який стосується преюдиційного запиту до Суду ЄС, має вирішити суд, який цей запит скерував, тобто Верховний Суд. Якщо Верховний Суд визнає, що Дисциплінарна Палата не $\epsilon$ незалежною та безсторонньою, може, відповідно до рішення Суду ЄС припинити застосування положень, згідно з якими до компетенції Дисциплінарної Палати належить розгляд спорів щодо переходу у стан спочинку (відставку) суддів Верховного Суду. Політики правлячої партії коментували у ЗМІ зазначене рішення з явною зневагою. Варто додати, що рішення Суду ЄС є обов'язковим для всіх органів влади та судів Польщі. Немає жодної можливості здійснення його перевірки жодною з палат Верховного Суду.

Варто звернути увагу, що на підставі вищезазначеного рішення Суду ЄС, Верховний Суд (який скерував преюдиційний запит до Суду ЄС) має підстави визнати, що Дисциплінарна Палата Верховного Суду «не є судом у розумінні права $€$, тому не $є$ судом в розумінні національного права», а КРС є «залежною від влади». Рішення було ухвалене у складі трьох суддів Палати Праці та Соціального Страхування²2.

Після рішення Суду ЄС I Голова Верховного Суду Малгожата Герсдорф звернулася з проханням до суддів Дисциплінарної Палати, щоб вони утрималися від винесення рішень. Натомість голова цієї Палати відповів, що Палата й надалі буде вчиняти дії, пов'язані з винесенням рішень у справах ${ }^{23}$. На жаль, $з$ огляду на ситуацію, що склалася, подальше винесення рішень Дисциплінарною Палатою матиме значні юридичні вади.

Суд ЄС проаналізував також важливі аспекти так званого рішення «португальського» 24 (йдеться про призупинення призначення суддів у Португалії) і підкреслив, що безсторонність суддів $є$ однією з конституційних цінностей Європейського Союзу, встановлених у ст. 2 Договору про Європейський Союз 25 .

Як вірно вказується у літературі, «на особливу увагу заслуговує позиція Суду, що суди мають бути незалежними, оскільки можуть застосовувати та інтерпретувати право ЄС. Суд не виніс рішення, що з перспективи права ЄС суди мають бути незалежними під час застосування та інтерпретації цього права. Іншими словами, порядок забезпечення державами-членами незалежності національних судів оновлюється у випадку встановлення, що національний орган є судом в розумінні права ЄС, а в його компетенції знаходиться тлумачення чи застосування права ЄС. В результаті вже з цього приводу Суд ЄС має компетенцію оцінювати чи норми національного законодавства щодо незалежності судів відповідають праву $Є С$ чи ні» ${ }^{26}$. Обгрунтованою $€$ оцінка, що «португальське» рішення є одним з найважливіших та переломних рішень Суду ЄС в історії європейської інтеграції, коли ж дає зелене світло системі права ЄС, щоб доповнити в компетенцію виключно держав-членів ЄС у сфері правосуддя і має важливе значення для спору між Європейською Комісією та Польщею щодо реформи польського судочинства ${ }^{27}$.

\footnotetext{
22 Sygnatura akt III PO 7/18, wyrok z 5 grudnia 2019 r. URL: http://www.sn.pl/sites/orzecznictwo/orzeczenia3/iii\%20po\%20718-2.pdf

23 Офіційний сайт новин телебачення TVN24.PL. Доповідь щодо діяльності Дисциплінарної палати Верховного Суду. URL: https://tvn24.pl/prezes-izby-dyscyplinarnej-sn-izba-bedzie-orzekac-reakcja-na-apel-malgorzaty-gersdorf,992209,s.html

24 Wyrok TS z 27 lutego 2018 r., sprawa C-64/16. Associação Sindical dos Juízes Portugueses p. Tribunal de Contas. ECLI:EU:C:2018:117.

25 Garlicki L. Europejski nakaz aresztowania - dialogu ciąg dalszy (w:) Serowaniec M., Bień A. - Kacała, Kustra-Rogatka A. (red.), Potentia non est nisi da bonum. Księga Jubileuszowa dedykowana Profesorowi Zbigniewowi Witkowskiemu. Toruń 2018. s.255. Por. także Barcik J. Barcik J. Niezawisłość sędziowska jako wartość konstytucyjna UE.Europejski Przegląd Sądowy” nr 5/2018. s. 23 i n.

26 Bogdanowicz P. Jak Trybunał Sprawiedliwości „aktywował” art. 19 ust. 1 TUE w kontekście praworządności: uwagi na tle sprawy C-64/16 Associação Sindical dos Juízes Portugueses (w:) Barcz J., Zawidzka-Łojek A. (red.). Sądowe mechanizmy ochrony praworządności w Polsce w świetle najnowszego orzecznictwa Trybunału Sprawiedliwości UE. Warszawa 2018. s. 69. Por. także cytowana tam literatura.

27 Там само. С. 71.
} 
Згодом важливим вирішенням було рішення від 25 липня 2018 р. у справі LM28, винесене в порядку преюдиційного запиту, скерованого до Суду ЄС ірландським судом - а саме, чи можна в актуальній ситуації польського правосуддя, відповідно до права ЄС, виконати польський Європейський Наказ Арешту. Два зазначені рішення: «португальське» і у справі LM, є дуже цікавими та багатим матеріалом, що може стати відправною точкою для розгляду справи кожної держави $з$ проблемами верховенства права, яка порушує незалежність судів та безсторонність суддів.

\section{Висновки}

Як справедливо зазначає колишня прем'єр-міністр Польщі Анна Сухоцька (notabene членкиня Венеційської Комісії), на етапі роботи над Конституцією Польщі у дев'яностих роках не передбачалося напруження та суперечностей між судовою владою та виконавчою владою і одночасно вважалося, що класична концепція поділу влади, яка гарантує те, що у цій системі $є$ найважливіше, тобто принцип незалежності та автономії судової влади, і що важливим правилом $\epsilon$ те, що екзекутивний тиск на суди - це завжди явище патологічне, осудне і таке, що порушує Конституцію29.

Вчинення дій, які суперечать принципу верховенства права для держави-члена Європейського Союзу, є явищем «самомаргіналізації» і заштовхування себе в так званий «куток». Варто підкреслити, що абсолютно недопустимим $є$ те, щоб представники інших сегментів влади підривали своїми висловлюваннями позиції суддів та довіру громадськості до судів. Дискредитація «третьої влади» в очах громадськості є замахом на незалежність судів та безсторонність суддів, а дії, вчинені задля короткотермінових політичних вигод, вдаряють по демократичній правовій державі, а також, власне, по її громадянах та їх праві на справедливий суд, і у такий спосіб по їхніх громадянських правах і свободах ${ }^{30}$.

На жаль, можна без оптимізму підтримати думку, висловлену в літературі, що незалежно від того, які ще рішення щодо Польщі прийматиме Суд ЄС, саме Польща стала першою державоючленом $€ C$, щодо якої розпочато процедуру захисту верховенства права на підставі ст. 7 Договору про ЄС, а наслідки порушення цінностей ЄС будуть відчутні та серйозні для Польщі, натомість дії польської влади після 2015 року трактуються партнерами в Європейському Союзі як «прояв авторитарних тенденцій», що загрожують європейській інтеграції значно більшою мірою, ніж Brexit 31 .

\section{Переклад з польської мови: Христина Потапенко}

\footnotetext{
28 Wyrok Trybunału Sprawiedliwości z dnia 25 lipca 2018 r. Minister for Justice and Equality v. LM (C-216/18 PPU, ECLI:EU:C:2018:586), nazywany tė̇ „sprawą Celmera”. Por. L. Garlicki,op.cit., s. 250 i n. Szczegółowo o orzeczeniu tym i jego następstwach piszą również M. Taborowski oraz Frąckowiak-Adamska A. Taborowski M., Naruszenie elementów zasady państwa prawa (art.2 TUE) jako ograniczenie zasady wzajemnego zaufania w prawie Unii Europejskiej (w świetle wyroku LM (Celmer) oraz A. Frąckowiak - Adamska, Następstwa wyroku w sprawie LM (Celmer) i postępowania na podstawie art. 7 TUE dla funkcjonowania sądów polskich w ramach wspólnoty prawnej (w:) J. Barcz, A. Zawidzka-Łojek (red.), Sądowe mechanizmy ochrony praworządności w Polsce w świetle najnowszego orzecznictwa Trybunału Sprawiedliwości UE. Warszawa 2018. s. 73 i n. oraz s. 89 i n.

${ }^{29}$ Suchocka H. Wokół standardów europejskich dotyczących powoływania sędziów sądów (z doświadczeń Komisji Weneckiej) (w:) Serowaniec M., Bień - Kacała A., Kustra-Rogatka A. (red.), Potentia non est nisi da bonum. Księga Jubileuszowa dedykowana Profesorowi Zbigniewowi Witkowskiemu. Toruń 2018. s. 750-751.

30 Zawistowski D. Niezależność sądów i niezawisłość sędziów z perspektywy prawa Unii Europejskiej.Ruch Prawniczy, Ekonomiczny i Socjologiczny". z. 2/2016, s.13.

31Majkowska-Szulc S. Konsekwencje naruszenia wartości Unii Europejskiej na przykładzie unicestwienia polskiego Trybunału Konstytucyjnego w 20 lat po uchwaleniu Konstytucji RP. „Gdańskie Studia Prawnicze”. t. XL. 2018. s. $712-713$.
} 


\section{Список використаних джерел}

\section{Бібліографія:}

1. Barcz J. Podsumowanie i wnioski (w:) Barcz J., Zawidzka-Łojek A. (red.). Sądowe mechanizmy ochrony praworządności w Polsce w świetle najnowszego orzecznictwa Trybunału Sprawiedliwości UE. Warszawa 2018.

2. Barcik J. Niezawisłość sędziowska jako wartość konstytucyjna UE.Europejski Przegląd Sądowy" nr 5/2018.

3. Bogdanowicz P. Jak Trybunał Sprawiedliwości „aktywował” art. 19 ust. 1 TUE w kontekście praworządności: uwagi na tle sprawy C-64/16 Associação Sindical dos Juízes Portugueses (w:) Barcz J., Zawidzka-Łojek A. (red.). Sądowe mechanizmy ochrony praworządności w Polsce w świetle najnowszego orzecznictwa Trybunału Sprawiedliwości UE. Warszawa 2018.

4. Garlicki L. Europejski nakaz aresztowania - dialogu ciąg dalszy (w:) M. Serowaniec, A. Bień - Kacała, A. Kustra-Rogatka (red.), Potentia non est nisi da bonum. Księga Jubileuszowa dedykowana Profesorowi Zbigniewowi Witkowskiemu. Toruń 2018.

5. Majkowska-Szulc S. Konsekwencje naruszenia wartości Unii Europejskiej na przykładzie unicestwienia polskiego Trybunału Konstytucyjnego w 20 lat po uchwaleniu Konstytucji RP. „Gdańskie Studia Prawnicze”. t. XL. 2018.

6. Suchocka H. Wokół standardów europejskich dotyczących powoływania sędziów sądów (z doświadczeń Komisji Weneckiej) (w:) M. Serowaniec, A. Bień - Kacała, A. Kustra-Rogatka (red.), Potentia non est nisi da bonum. Księga Jubileuszowa dedykowana Profesorowi Zbigniewowi Witkowskiemu. Toruń 2018.

7. Szmyt A. Destrukcja Trybunału Konstytucyjnego w Polsce w świetle opinii Komisji Weneckiej.Gdańskie Studia Prawnicze. Tom XL. 2018.

8. Tezy wystąpienia Rzecznika Praw Obywatelskich z dnia 20.12.2019 r. w Sejmie. URL: https://www.rpo.gov.pl/pl/content/rpo-w-sejmie-ten-projekt-dewastuje-procedury-sadowe-i-grozi-polexitem (dostęp 2.1.2020).

9. Zawistowski D. Niezależność sądów i niezawisłość sędziów z perspektywy prawa Unii Europejskiej.Ruch Prawniczy, Ekonomiczny i Socjologiczny". Z. 2/2016.

10. Офіційний веб-сайт електронної газети «Rzeczpospolita». Розділ: Право.URL: URL: https://www.rp.pl/Sedziowie-isady/309179953-KRS-zawieszona-w-Europejskiej-Sieci-Rad-Sadownictwa.html

11. Офіційний веб-сайт електронної газети «Newsweek Polska». Розділ: Політика. URL: https://www.newsweek.pl/polska/polityka/komisja-europejska-interweniuje-w-sprawie-sadow-chce-wstrzymania-pracnad-ustawa/k9fek5g

12. Офіційний веб-сайт електронної газети «Newsweek Polska». Розділ: Політика. URL: https://www.newsweek.pl/polska/polityka/sejm-uchwalil-ustawe-kagancowa-pis-blyskawicznie-przepycha-noweprzepisy/x6qf32p

13. Офіційний веб-сайт електронної газети «OKO.press». Доповідь Проф. Еви Летовської. URL: https://oko.press/profletowska-to-projekt-niekonstytucyjny-niedemokratycznie-obrazliwy-dokonuje-siepolexit/?utm_medium=Social\&utm_source=Facebook\&fbclid=IwAR3vHxWzgzvzMGh3P0VPZL2Vc8dh_DBVqy8oWhu_Y76W qoW4HkJ4Z_bGcEI\#Echobox=1576196077

14. Офіційний веб-сайт польського радіо RMF24. URL: https://www.google.pl/amp/s/www.rmf24.pl/newsamp-mamy-pelnatresc-postanowienia-tsue,nld,2646857

15. Офіційний сайт новин телебачення TVN24.PL. Доповідь Президента Польщі. URL:https://www.tvn24.pl/wiadomosci-zkraju,3/prezydent-o-sedziach-i-reformie-sadownictwa,896188.html

16. Офіційний сайт новин телебачення TVN24.PL. Доповідь щодо діяльності Дисциплінарної палати Верховного Суду. URL: gersdorf,992209,s.html https://tvn24.pl/prezes-izby-dyscyplinarnej-sn-izba-bedzie-orzekac-reakcja-na-apel-malgorzaty-

\section{Перелік юридичних документів:}

1. Dz. U. z 20 grudnia 2015 p. poz.1928. URL: http://prawo.sejm.gov.pl/isap.nsf/download.xsp/WDU20150001928/T/D20151928L.pdf

2. Dz. U. z 1 sierpnia 2016 p. poz. 1157. URL: http://prawo.sejm.gov.pl/isap.nsf/download.xsp/WDU20160001157/T/D20161157L.pdf

3. Dz.U. z 2018 r. poz. 3, Dz.U. z 2019 r. poz. 84 tekst jednolity.

4. Opinia Komisji Weneckiej z dnia 11 marca 2016 r. W sprawie zmiany ustawy o Trybunale Konstytucyjnym z dnia 22 grudnia 2015 r.,Opinion on amendments to the Act of 25 June 2015 on the Constiututional Tribunal of Poland, adopted by the Venice Commission at its 106th Plenary Session (venice,11-12 March 2016), CDL-Ad (2016) 001-e.

5. Opinia Komisji Weneckiej z dnia 14 października 2016 r. Opinion on the Act on the Constitutional Tribunal, adopted by the Venice Commission at its 108th Plenary Session (Venice,14-15 October), CDL-AD (2016) 026-e.

6. Opinion on the Draft Act amending the Act on the National Council of the Judiciary; on the Draft Act amending the Act on the Supreme Court, proposed by the President of Poland, and on the Act on the Organisation of Ordinary Courts, adopted by the Commission at its 113th Plenary Session (Venice, 8-9 December 2017), CDL-AD(2017)031-ePoland.

7. Sprawa C-619/18R Komisja p. Polsce. ECLI:EU:C: 2018:910, Tekst postanowienia dostępny jest na stronie. URL: https://curia.europa.eu/jcms/upload/docs/application/pdf/2018-10/cp180159pl.pdf 
8. Sygnatura akt III PO 7/18, wyrok z 5 grudnia 2019 r. URL: http://www.sn.pl/sites/orzecznictwo/orzeczenia3/iii\%20po\%207-18-2.pdf

9. Trybunał Sprawiedliwości Unii Europejskiej KOMUNIKAT PRASOWY nr 145/19Luksemburg, 19 listopada 2019r. URL: http://n-5-16.dcs.redcdn.pl/file/o2/tvn/web-content/m/p1/f/de03beffeed9da5f3639a621bcab5dd4/ac2d25fd-a754-4f518399-b606d3db5c32.pdf

10. Ustawa z dnia 8 grudnia 2017 r. o Sądzie Najwyższym, Dz. U. z 2018 r. poz. 5. z późn. zm.

11. Ustawa o zmianie ustawy - Prawo o ustroju sądów powszechnych, ustawy o Sądzie Najwyższym oraz niektórych innych ustaw,uchwalona na pos. nr 2 dnia 20-12-2019. URL: http://orka.sejm.gov.pl/opinie9.nsf/nazwa/69_u/\$file/69_u.pdf

12. Ustawa z dnia 21 listopada 2018 r. o zmianie ustawy o Sądzie Najwyższym, Dz. U. z 2018 r., poz. 2507.

13. Trybunał Sprawiedliwości Unii Europejskiej KOMUNIKAT PRASOWY nr 145/19Luksemburg, 19 listopada 2019r. URL: http://n-5-16.dcs.redcdn.pl/file/o2/tvn/web-content/m/p1/f/de03beffeed9da5f3639a621bcab5dd4/ac2d25fd-a754-4f518399-b606d3db5c32.pdf

14. Wyrok TS z 19.11.2019 r. w składzie Wielkiej Izby w sprawach połączonych C-585/18, C-624/18iC-625/18A.K. / Krajowa Rada Sądownictwa oraz CPiDO / Sąd Najwyższy, W przedmiocie pytania pierwszego w sprawach C 624/18 iC625/18 W przedmiocie pytań w sprawie C 585/18 oraz pytań drugiego i trzeciego w sprawach C624/18 iC625/18, W przedmiocie dopuszczalności pytań drugiego i trzeciego w sprawach C 624/18 iC625/18W przedmiocie merytorycznego rozpoznania pytań drugiego i trzeciego w sprawach C 624/18 iC625/18. URL: http://n-16-2.dcs.redcdn.pl/file/o2/tvn/web-content/m/p1/f/de03beffeed9da5f3639a621bcab5dd4/04584076-bc7e-4058-94fa-2eb6c31b3c70.pdf

15. Wyrok NSA z 28 czerwca 2019 r., sygn., akt. I OSK, 4282/18. URL: http://n-22-3.dcs.redcdn.pl/file/o2/tvn/web-content/m/p1/f/5bce843dd76db8c939d5323dd3e54ec9/193978e1-5cd4-4cd9-8d01-ae5002551c87.pdf (dostęp: 5.12.2020).

16. Wyrok TS z 27 lutego 2018 r., sprawa C-64/16, Associação Sindical dos Juízes Portugueses p. Tribunal de Contas, ECLI:EU:C:2018:117.

17. Wyrok Trybunału Sprawiedliwości z dnia 25 lipca 2018 r. Minister for Justice and Equality v. LM (C-216/18 PPU, ECLI:EU:C:2018:586)

\section{References}

\section{Bibliography:}

1. Barcz J. Podsumowanie i wnioski (w:) Barcz J., Zawidzka-Łojek A. (red.). Sądowe mechanizmy ochrony praworządności w Polsce w świetle najnowszego orzecznictwa Trybunału Sprawiedliwości UE. Warszawa 2018. s. 150.

2. Barcik J. Niezawisłość sędziowska jako wartość konstytucyjna UE.Europejski Przegląd Sądowy” nr 5/2018. s. 23 i n.

3. Bogdanowicz P. Jak Trybunał Sprawiedliwości „aktywował” art. 19 ust. 1 TUE w kontekście praworządności: uwagi na tle sprawy C-64/16 Associação Sindical dos Juízes Portugueses (w:) Barcz J., Zawidzka-Łojek A. (red.). Sądowe mechanizmy ochrony praworządności w Polsce w świetle najnowszego orzecznictwa Trybunału Sprawiedliwości UE. Warszawa 2018. s. 69.

4. Garlicki L. Europejski nakaz aresztowania - dialogu ciąg dalszy (w:) M. Serowaniec, A. Bień - Kacała, A. Kustra-Rogatka (red.), Potentia non est nisi da bonum. Księga Jubileuszowa dedykowana Profesorowi Zbigniewowi Witkowskiemu. Toruń 2018. s.255.

5. Majkowska-Szulc S. Konsekwencje naruszenia wartości Unii Europejskiej na przykładzie unicestwienia polskiego Trybunału Konstytucyjnego w 20 lat po uchwaleniu Konstytucji RP. „Gdańskie Studia Prawnicze”. t. XL. 2018. s. 712-713.

6. Ofitsiinyi veb-sait elektronnoi hazety «Newsweek Polska». Rozdil: Polityka. URL: https://www.newsweek.pl/polska/polityka/komisja-europejska-interweniuje-w-sprawie-sadow-chce-wstrzymania-prac-nad-ustawa/k9fek5g

7. Ofitsiinyi veb-sait elektronnoi hazety «Newsweek Polska». Rozdil: Polityka. URL: https://www.newsweek.pl/polska/polityka/sejm-uchwalil-ustawe-kagancowa-pis-blyskawicznie-przepycha-nowe-przepisy/x6qf32p

8. Ofitsiinyi veb-sait elektronnoi hazety «OKO.press». Dopovid Prof. Evy Letovskoi. URL: https://oko.press/prof-letowska-toprojekt-niekonstytucyjny-niedemokratycznie-obrazliwy-dokonuje-sie-polexit/?utm_medium=Social\&utm_source=Facebook\&fbclid=IwAR3vHxWzgzvzMGh3P0VPZL2Vc8dh_DBVqy8oWhu_Y76WqoW4HkJ4Z_bGcEI\#Echobox=1576196077

9. Ofitsiinyi veb-sait polskoho radio RMF24. URL: https://www.google.pl/amp/s/www.rmf24.pl/newsamp-mamy-pelna-trescpostanowienia-tsue,nld,2646857

10. Ofitsiinyi sait novyn telebachennia TVN24.PL. Dopovid Prezydenta Polshchi. URL: https://www.tvn24.pl/wiadomosci-zkraju,3/prezydent-o-sedziach-i-reformie-sadownictwa,896188.html

11. Ofitsiinyi veb-sait elektronnoi hazety «Rzeczpospolita». Rozdil: Pravo. URL: https://www.rp.pl/Sedziowie-isady/309179953-KRS-zawieszona-w-Europejskiej-Sieci-Rad-Sadownictwa.html

12. Ofitsiinyi sait novyn telebachennia TVN24.PL. Dopovid shchodo diialnosti Dystsyplinarnoi palaty Verkhovnoho Sudu. URL: https://tvn24.pl/prezes-izby-dyscyplinarnej-sn-izba-bedzie-orzekac-reakcja-na-apel-malgorzaty-gersdorf,992209,s.html

13. Suchocka H. Wokół standardów europejskich dotyczących powoływania sędziów sądów (z doświadczeń Komisji Weneckiej) (w:) M. Serowaniec, A. Bień - Kacała, A. Kustra-Rogatka (red.), Potentia non est nisi da bonum. Księga Jubileuszowa dedykowana Profesorowi Zbigniewowi Witkowskiemu. Toruń 2018. s. 750-751. 
14. Szmyt A. Destrukcja Trybunału Konstytucyjnego w Polsce w świetle opinii Komisji Weneckiej.Gdańskie Studia Prawnicze. Tom XL. 2018. s. 660.

15. Tezy wystąpienia Rzecznika Praw Obywatelskich z dnia 20.12.2019 r. w Sejmie. URL: https://www.rpo.gov.pl/pl/content/rpo-w-sejmie-ten-projekt-dewastuje-procedury-sadowe-i-grozi-polexitem (dostęp 2.1.2020).

16. Zawistowski D. Niezależność sądów i niezawisłość sędziów z perspektywy prawa Unii Europejskiej.Ruch Prawniczy, Ekonomiczny i Socjologiczny". z. 2/2016. s.13.

\section{List of legal documents:}

1. Dz. U. z 20 grudnia 2015 p. poz.1928. URL: http://prawo.sejm.gov.pl/isap.nsf/download.xsp/WDU20150001928/T/D20151928L.pdf

2. Dz. U. $\mathrm{z} \quad 1$ sierpnia 2016 p. poz. 1157. URL: http://prawo.sejm.gov.pl/isap.nsf/download.xsp/WDU20160001157/T/D20161157L.pdf

3. Dz.U. z 2018 r. poz. 3, Dz.U. z 2019 r. poz. 84 tekst jednolity.

4. Opinia Komisji Weneckiej z dnia 11 marca 2016 r. W sprawie zmiany ustawy o Trybunale Konstytucyjnym z dnia 22 grudnia 2015 r.,Opinion on amendments to the Act of 25 June 2015 on the Constiututional Tribunal of Poland, adopted by the Venice Commission at its 106th Plenary Session (venice,11-12 March 2016), CDL-Ad (2016) 001-e.

5. Opinia Komisji Weneckiej z dnia 14 października 2016 r. Opinion on the Act on the Constitutional Tribunal, adopted by the Venice Commission at its 108th Plenary Session (Venice,14-15 October), CDL-AD (2016) 026-e.

6. Opinion on the Draft Act amending the Act on the National Council of the Judiciary; on the Draft Act amending the Act on the Supreme Court, proposed by the President of Poland, and on the Act on the Organisation of Ordinary Courts, adopted by the Commission at its 113th Plenary Session (Venice, 8-9 December 2017), CDL-AD(2017)031-ePoland.

7. Sprawa C-619/18R Komisja p. Polsce. ECLI:EU:C: 2018:910, Tekst postanowienia dostępny jest na stronie. URL: https://curia.europa.eu/jcms/upload/docs/application/pdf/2018-10/cp180159pl.pdf

8. Sygnatura akt III PO 7/18, wyrok z 5 grudnia 2019 r. URL: http://www.sn.pl/sites/orzecznictwo/orzeczenia3/iii\%20po\%207-18-2.pdf

9. Trybunał Sprawiedliwości Unii Europejskiej KOMUNIKAT PRASOWY nr 145/19Luksemburg, 19 listopada 2019r. URL: http://n-5-16.dcs.redcdn.pl/file/o2/tvn/web-content/m/p1/f/de03beffeed9da5f3639a621bcab5dd4/ac2d25fd-a754-4f518399-b606d3db5c32.pdf

10. Ustawa z dnia 8 grudnia 2017 r. o Sądzie Najwyższym, Dz. U. z 2018 r. poz. 5. z późn. zm.

11. Ustawa o zmianie ustawy - Prawo o ustroju sądów powszechnych, ustawy o Sądzie Najwyższym oraz niektórych innych ustaw,uchwalona na pos. nr 2 dnia 20-12-2019. URL: http://orka.sejm.gov.pl/opinie9.nsf/nazwa/69_u/\$file/69_u.pdf

12. Ustawa z dnia 21 listopada 2018 r. o zmianie ustawy o Sądzie Najwyższym, Dz. U. z 2018 r., poz. 2507.

13. Trybunał Sprawiedliwości Unii Europejskiej KOMUNIKAT PRASOWY nr 145/19Luksemburg, 19 listopada 2019r. URL: http://n-5-16.dcs.redcdn.pl/file/o2/tvn/web-content/m/p1/f/de03beffeed9da5f3639a621bcab5dd4/ac2d25fd-a754-4f518399-b606d3db5c32.pdf

14. Wyrok TS z 19.11.2019 r. w składzie Wielkiej Izby w sprawach połączonych C-585/18, C-624/18iC-625/18A.K. / Krajowa Rada Sądownictwa oraz CPiDO / Sąd Najwyższy, W przedmiocie pytania pierwszego w sprawach C 624/18 iC625/18 W przedmiocie pytań w sprawie C 585/18 oraz pytań drugiego i trzeciego w sprawach C624/18 iC625/18, W przedmiocie dopuszczalności pytań drugiego i trzeciego w sprawach C 624/18 iC625/18W przedmiocie merytorycznego rozpoznania pytań drugiego i trzeciego w sprawach C 624/18 iC625/18. URL: http://n-16-2.dcs.redcdn.pl/file/o2/tvn/web-content/m/p1/f/de03beffeed9da5f3639a621bcab5dd4/04584076-bc7e-4058-94fa-2eb6c31b3c70.pdf

15. Wyrok NSA z 28 czerwca 2019 r., sygn., akt. I OSK, 4282/18. URL: http://n-22-3.dcs.redcdn.pl/file/o2/tvn/web-content/m/p1/f/5bce843dd76db8c939d5323dd3e54ec9/193978e1-5cd4-4cd9-8d01-ae5002551c87.pdf (dostęp: 5.12.2020).

16. Wyrok TS z 27 lutego 2018 r., sprawa C-64/16, Associação Sindical dos Juízes Portugueses p. Tribunal de Contas, ECLI:EU:C:2018:117.

17. Wyrok Trybunału Sprawiedliwości z dnia 25 lipca 2018 r. Minister for Justice and Equality v. LM (C-216/18 PPU, ECLI:EU:C:2018:586) 